\title{
The Restatement of Contracts and Consideration
}

\author{
TWO ANGLES OF APPROACH
}

Several years ago a thoughtful student of law wrote:

"In spite of all that has been written and said in explanation of the doctrine of consideration, the law is still far from clear upon the subject. The courts are not consistent in their application of the rule, partly because they are unwilling to enforce it strictly in all cases, and partly because they are often hazy in their understanding and knowledge of the topic. All this leads to present uncertainty and doubt. It is further true that consciously or not the law of consideration is being modified gradually, until the present technical requirement is likely to be entirely abolished."

The present writer believes that Dean Ashley's quoted statements are still true except his conclusion that the "technical requirement is likely to be entirely abolished." The indications of coming abohtion are not numerous. But there is evidence of an unwillingness to apply it rigidly, of a desire to be reasonable about it.

In Hurlbut v. Butte-Kansas Company ${ }^{2}$ the defendant rented four acres from the plaintiff at $\$ 40$ a month, the rent to start after a year of occupancy in consideration of certain expenditures for improvements to be made by the lessee. Rent being due for the second year and unpaid, the lessor demanded it. The lessee replied that the improvements he had made had cost three times the contemplated amount and asked an adjustment. The lessor then "waived" all rent for the four acres. This waiver was relied on as a defense to a suit for rent. The lessor argued that "such agreement was not binding for a lack of consideration." The court said:

"Treating this as a waiver of rent, a consideration is not necessary in all cases to support a waiver, it being a mere voluntary relinquishment of a known right."3

But in Kansas part-payment of a debt cannot serve as consideration for a relinquishment of the balance. ${ }^{4}$ Thus by the instant case nonpayment is better than part-payment. Something might have been said long ago in favor of confining the doctrine of consideration to cases involving the creation of new contract obligations and accordingly of refusing to apply it to the discharge of contract rights, just as now the

1 Ashley, The Doctrine of Consideration (1913) 26 HaRv. L. REv. 429.

2 (1926) 120 Kan. 205, 243 Pac. 324.

$3120 \mathrm{Kan}$. at 206, $243 \mathrm{Pac}$. at 325.

4 American Bridge Co. v. Murphy (1874) 13 Kan. 33; McGregor v. Farmer's Bank (1923) 114 Kan. 356, 219 Pac. 520. 
courts generally do not apply it to the waiver of defenses. ${ }^{5}$ But the time for such argument seems to have passed; it is clear that in general a consideration is required for the discharge of an obligation. Of course releases under seal, the written surrender of rights on negotiable paper and some other situations must be distinguished. So our Kansas court in Hurlbut v. Butte-Kansas Company, supra, certainly refused to abide by the prevailing doctrine concerning consideration. A consistent application of their decision would abohish the doctrine as applied to contracts to discharge rights. ${ }^{6}$ And there are similar decisions on like or analogous facts. ${ }^{7}$

In Southern Pacific Company v. United States ${ }^{8}$ the plaintiff carried many persons, applicants for enlistment in the army, discharged soldiers and civilian employees, for the War Department. The railway was bound under an agreement with the government to carry troops at lialf rates. The government officials took the erroneous position that these other persons carried were within the meaning of "troops." The railway thereupon presented bills for their carriage at half rates and was paid. It was held that, except where the railway protested that it did not waive its claim to full fares, it had lost its right to full fares by acquiescence, abandonment or waiver. The court said:

"Manifestly there was here 'no accord and satisfaction or compromise of a disputed claim.' The claimant, while presenting its bills for transportation at the land-grant (50\%) rates and accepting payment thereof, did not execute either a receipt in full for its transportation charges or a release thereof. The crucial question then is whether the conduct of the claimant with reference to the acceptance of the land-grant rates establishes an acquiescence in the payment thereof, in the nature of an abandonment or waiver, that operated as a discharge of its claim for the full passenger rates," 9

Thus does the highest tribunal in the United States readily permit part payment to be taken in full satisfaction of a claim against the government.

In Blakeslee v. Board ${ }^{10}$ the Supreme Court of Connecticut decided that it was possible to uphold a contract in which one party promised

5 This matter is discussed below, page 627 , et seq.

6 It is true that they also suggested that there was a consideration in the making of the improvements. But the improvements had been made and the price promised for them, one year's freedom from rent had been given. The suggested consideration was past and not within the historical exception to the general insufficiency of past consideration because this past consideration had been paid for when given.

7 See Note (1926) 43 A. L. R. 1451, 1480.

8 (1925) 268 U. S. 263 , 45 Sup. Ct. 500.

${ }^{9} 268$ U. S. at 268,45 Sup. Ct. at 502.

10 (1927) 106 Conn. 642, 139 Att. 106. 
a different and larger compensation for the doing of work the other party was bound to the former to do. The chief point relied upon perhaps was that the incidence of the war had made the contractor's obligation so burdensome financially that there was no extortion in his asking extra pay and that under such circumstances doing what one is bound to do may be permitted to serve as a consideration.

It is obvious that courts of the highest standing will often depart from the rigors of the generally accepted doctrines of consideration.

Farther on in the same article Dean Ashley says:

"We still maintain as requisite a technicality existing simply because of its historical developinent, and involving such an important topic as contract. We envelop an obligation of every day use with a legal rule, which is unnecessary, and which frequently works rank injustice. In view of this and other outgrown doctrines, it is not strange that the commonsense intelligence of the people leads them to regard law and lawyers with suspicion.

"A technical rule, however liarsh, is less objectionable if clearly understood and consistently applied. Men may shape their conduct to meet the requirement. But the doctrine of consideration is not so enforced. Neither courts nor thinking writers are willing to follow fearlessly wherever the rule may lead." 11

The present writer would amend this statement somewhat. Probably the doctrine of consideration has some utility. Just as oral gifts are invalid without delivery, so promises not under seal are invalid unless there is an exchange given for them. The aims in both cases are to make more certain that the transaction was seriously intended and to make more difficult the fabrication of a gift or a contract. Justice Holmes long ago said:

". . Consideration is as much a form as a seal."12

This notion should be constantly kept in mind. The question should be: Has there been something given for this promise which shows us that it was seriously meant and which convinces us of its genuineness? If such a test were applied, many of the nice problems of consideration, interesting as intellectual entertainment but unhappily serious to disappomted litigants, would disappear. The law of consideration needs reform; it needs a fundamental restatement; it needs to be modernized. It is over-technical to an extent which only one who has studied it with care can fully realize. Instead of effectuating the intentions of the parties, it frequently frustrates them.

Too often the difference between valid consideration and an in-

11 Ashley, op. cit. supra note 1 , at 435 .

12 Krell v. Codman (1891) 154 Mass. $454,456,28$ N. E. $573,578,14$ L. R. A. 860, 862, 26 Am. St. Rep. 260, 261. 
valid one is the difference between tweedle-dum and tweedle-dee. One receives two offers requiring identical promises as acceptance - say offers of sums of money for a promise to build a house of a given value on a certain lot within a year. Two letters of acceptance are written. If they are mailed at the same time each promise is a valid consideration for the promise contained in the offer it accepts. ${ }^{13}$ But if one be mailed first then the acceptor, thereby becoming bound on that acceptance, furnishes no sufficient consideration when he mails the second acceptance promising the same thing. ${ }^{14}$ When chance is permitted to settle important legal rights, and few laymen are skilled enough in the law of consideration to act with an understanding of the consequences of this or that difference in their conduct, we are to some extent back in the age of trial by ordeal.

What then should be the attitude of a forward-looking lawyer, judge or restating committee toward this doctrine of consideration? It would seem that such a person or persons should desire to avoid any extension of the doctrine and should wish to limit it to its proper function ${ }^{15}$ wherever possible. Such a person was Dean James Barr Ames of the Harvard Law School. He saw the absurdities of the present over-refined law and suggested in two brilliant articles ${ }^{10}$ a way to rid the law of many, if not most of them. Laying minor suggestions aside, the main point he made was that the common view that doing what you are bound to do cannot be a detriment, is wrong. He pointed out that the law had not always recognized any such principle, that the law today has departed from it in some cases, that particular applications of it have been criticized as unjust by both courts and writers, and that its application in certain situations leads to results which are indefensible, not to say fantastic. This view of Dean Ames, that whether one is already bound or not is immaterial to the sufficiency as consideration of an act or promise, may be called the Ames theory. Opposed to this stands the commonly accepted doctrine, that doing or promising what you are already bound to do

13 Champlam Co. v. O'Brien (C. C. D. Ver. 1902) 117 Fed. 271; Ophir Co. v. Brynteson (1906) 143 Fed. 829, 834; Bailey v. Croft (1812) 4 Taunt. 611; Koh-i-moor Laundry Company v. Lockwood (1894) 141 Ind. 140; 1 Wuriston, Contracts (1920) \$131b. But see contra: Bush v. Rawlins (1892) $89 \mathrm{Ga} .117$, 5 S. E. 761 ; Petze v. Leary (1907) 117 App. Div. 829, 102 N. Y. Supp. 960.

141 Wrisiston, Contracts (1920) §131a. Professor Williston, while insisting that in such third party cases there is a benefit to the promisor though no detriment to the promisee and that therefore the second contract should he good, admits that the distinct weight of cases is against his view.

15 See stipra page 613.

16 Ames, Two Theories of Consideration (1899) 12 Harv. L. Rev. 515, (1899) 13 Harv. L. REv. 29, reprinted with corrections in AMES, Lectures on LeGAL HTSTORY (1913) 323-353. 
cannot be a legal detriment and this is the view adopted in the Restatement. It may be called the "orthodox" theory, meaning by the adjective that it is the commonly accepted or conventional theory. There is a third theory which is worth considering. It may be called the "detriment" theory. It concedes that there must be a legal detriment to someone other than the promisor or a legal benefit to the promisor to constitute a sufficient consideration. It admits that the fact that one is already bound to do an act is strong evidence that the doing or promising to do the act is not a detriment. But it maintains that a detriment under such circumstances is not impossible and it sees no objection either to admitting the existence of such a detriment when present or to holding that such a detriment makes the consideration sufficient. An illustration will perhaps make this theory more real to the reader. $A$ and $B$ are jointly bound to pay a debt. $A$, in consideration of some new promise by the creditor, promises the creditor to pay the debt. He was already bound to pay it by his joint promise. On the "orthodox" theory the new promise is an insufficient consideration, and Professor Williston so considers it. ${ }^{17}$ But by the "detriment" theory the new promise to pay is a sufficient consideration since it is a legal detriment in that it subjects $A^{\prime}$ to a suit to which $B$ is not a necessary party. The cases generally, as Professor Williston admits, sustain the consideration. ${ }^{18}$

The logic of this "detriment" theory is well-mgh unanswerable. It may be argued against it that the detriment present may be unknown to the parties or at least may not be present to their minds at the time of contracting and therefore should fail because not an intended consideration. But the answer seems obvious. While no act or promise is a consideration unless a part of the intended exchange yet it is quite unnecessary that the parties should know in what way such an act or promise is a legal detriment or intend anything as to that. The separate promise of the joint debtor, in the illustration above, is the intended consideration but it is not necessary that the parties should have known the law of joinder of parties or that they should have realized in what way the new promise created a detriment. This "detriment" theory would go far to undermine the "orthodox" theory since in most acts or promises of acts which one is already bound to do there is a legal detriment. For that reason it has not gained general acceptance. The "orthodox" theory has laid a heavy hand on contracts and nulhified them in very many cases where a detriment to the promisee was plainly present. The only apparent excuse for this is that it does

171 WIILISTON, Contracts (1920) $\$ 123$.

18 Ibid. 
very effectually prevent a person bound by a contract from extorting extra compensation for doing what he is under legal obligation to do. But the cure out-runs the evil. Any contract may properly be rescinded for extortion. ${ }^{19}$ That is a sufficient remedy. To strike down all contracts where extortion of a certain kind might have been present, though in many, probably most of them, it demonstrably was not present, is to create a very great injustice - the injustice of refusing to give effect to legitimate business transactions entered into by persons of full age. ${ }^{20}$

There are then two possible angles of approach to the task of restating the law of consideration. One views the doctrine with approval, considers the "orthodox" theory concerning acts or promises of acts which one is bound to do satisfactory, and attempts to apply this law fairly to old and new problems and even to extend it to situations hitherto not supposed to be within its sphere. The other views the technicalities of the doctrine of consideration with distaste, believes with Dean Ames and Justice Blackburn"1 that the "orthodox" theory was a mistake which should be himited in every practicable way and opposes any extension of the present over-refined and transactiondestroying doctrine to new fields. The Restatement seems generally but by no means always to approach each problem fron the former of these two positions. The writer would prefer the latter and therefore disagrees with a number of the conclusions reached. Some statement of these points of difference will now be attempted.

\section{OVER-CONSERVATIVE POSITIONS}

The most talked-of application of the "orthodox" theory is the resulting inability of a creditor to accept part payment of his debt as full satisfaction. This result has often been criticized.22 Of course if a smaller amount is taken because the payment is made prior to the maturity of the debt the settlement is effectual. By the Ames theory, that whether one is already bound is immaterial, the settlement would be binding. By the "detriment" theory it also would be valid since

19 Alaska Packers Association v. Domenico (C. C. A. 9th, 1902) 117 Fed. 99 ; Rowland v. Watson (I906) 4 Cal. App. 476, 88 Pac. 495; Missouri, Kansas and Texas Ry. v. Pacheco (1916) 185 S. W. 1051 (Tex. Civ. App.); 3 Wuriston, Contracts (1920) \$1601ff., especially \$1620; 1 PaGe, Contracts (2d ed. 1920) \$436ff., especially \$\$491-492; Corbin, Pre-existing Duty and Consideration (1918) 27 YaIE L. J. 362, 372-374. See also Hartsville Oil Mill v. U. S. (1926) 271 U. S. 43,46 Sup. Ct. 389.

20 The restating committee writes in a note to $\$ 84:$ "If there is any doubt it seems better to resolve it in favor of upholding a bargain than of overthrowing it."

21 Foakes v. Beer (1884) 9 A. C. 605.

22 (1899) 12 Harv. L. Rev. 525; Note (1908) 17 YaIe L. J. 470. 
the part payment would be a legal detriment in that it would waive the statute of bimitations so far as it had run except in those few jurisdictions where a writing is required. This has been held. ${ }^{23}$ The only exception would be a part payment on the day of maturity at which time the statute of hmitations would not have begun to run. It is conceded in the Restatement, Section 76, Illustration 3, that if the statute of himitations has fully run a waiver of its benefit is a good consideration. This shows the radical error of the "orthodox" theory. Like an ostrich, the moment it becomes frightened by the presence of a prior duty to make the payment, it sticks its head in the sand and refuses to see a detriment that is present and obvious to everyone not so blinded.

The Restatement adopts the "orthodox" theory in Sections 76 and 78. We must deal gently with it for this departure from principle. It was hard to do otherwise in the face of overwhelming authority. ${ }^{24}$ But certainly it should have jealously maintained all exceptions to the "orthodox" theory for which there was authority. Professor Williston, himself, has stated ${ }^{25}$ that in three states without a statute and in some fourteen others by statute, part payment may be taken as satisfaction, at least if a receipt in full is given. Now, in the absence of extortion, what reason can be adduced for forbidding a creditor, who is adult and sane, to obtain the actual advantage of settlement of his claim without suit even though he may accept a somewhat smaller sum than is due? Yet the Restatement in no way recognizes the growing authority in favor of the desirable minority view.

There are other recognized exceptions to the "orthodox" rule about part-payment upon which the Restatement has turned its back. We may mention a promise of payment by one already jointly bound to pay, ${ }^{26}$ a like promise by one already bound as a partner ${ }^{27}$ and a payment of the principal when the creditor agrees that such payment shall discharge certain interest due not by the terms of the contract but by operation of law. ${ }^{28}$ Some so-called exceptions to the part-payment

23 Stallings v. Johnson (1859) $27 \mathrm{Ga} .564$.

24 But the Restatement is capable of great independence. One example is its adoption of the rule in Bishop v. Eaton (1894) 161 Mass. 496, 37 N. E. 665, 42 Am. St. Rep. 437, despite the fact that it stands substantially alone ( 1 WintrsTON, CONTRACTS (1920) $\$ \$ 68-69 a$ ) and is expressly opposed in at least one case (Midland National Bank v. Security Co. (1924) 161 Minn. 30, 200 N. W. 851. The writer agrees that Bishop v. Eaton, supra, is much the best view that has been taken.

251 WIILTSTON, CoNTRACTS (1920) $\$ 120$.

26 Ibid. \$123.

27 Ibid. \$123.

28 Ibid. $\$ 127$. 
rule are not exceptions at all but situations where something more than, or different from the duty owed, is given as consideration. Thus if the debtor gives new security, transfers the note of a third party, promises to treat all his creditors alike or pays at a place where he is not bound to pay there is sufficient consideration if this variation from the duty was bargained for. In such cases there is consideration by any of the theories.

There is one situation in which the Restatement apparently has violated the "orthodox" theory and taken a liberal view. This is expressed in Section 76, Mlustration 4. It is there stated that when a debt is "unliquidated" or when the "existence or amount is honestly and reasonably disputed" a payment of "any amount" may be accepted as full payment. This is obviously true even by the orthodox theory when the whole debt is disputed or when the disputed part exceeds the amount which the creditor foregoes. In such cases there is some payment beyond what is admittedly due. The same thing would be true if the debt were uuliquidated, as distinguished from disputed, and a verdict of a jury fixing the amount at less than the sum paid would be sustained. Again we can see a payment beyond what is certainly due. But if the amount paid is only what is admittedly due the "orthodox" theory makes the consideration insufficient. This also would be true if the amount paid were no more than the smallest sustainable "liquidation" of the debt by a jury. $A$ fortiori it would be true if the amount paid were less than either of these last two mentioned sums. All these considerations cannot by any reasoming, however astute, be sustained by the "orthodox" theory. ${ }^{29}$ But the Restatement makes them all sufficient. I congratulate it. It is true that where the payment is of the exact amount admitted to be due there is abundant authority to sustain its sufficiency. ${ }^{30}$ But concerning payments of less than is admittedly due there is almost no case law. ${ }^{31}$

In Mlustration 4 to Section 76, just discussed, the qualification is added that the claim must be "honestly and reasonably" disputed. In Section 76, in both subsection (a) and subsection (b), reasonableness is added to honesty in defiming what disputes will affect consideration. This, of course, is carried over into the test for bilateral contracts by

${ }^{29}$ See, however, ibid. $\$ \$ 128,129$.

30 Ibid. \$129.

31 Huff v. Logan (1901) 60 S. W. 483, holds such a payment an insufficient consideration though the point was not discussed. See the decision on the demurrer to the petition as first amended. Note that the controversy alleged concerned only one note and so that it is fair to assume that the $\$ 125.00$ paid was less than the amount admittedly due. Note also that the court, perhaps erroneously, treated all three notes as parts of a single debt. 
Section 78. So the position of the Restatement is that the compromise of an honest claim is not enough - the claim must also be reasonable. All students of contracts know that originally a compromise was held to lack consideration unless the claim compromised was valid. Then it was conceded that a compromise of a claim doubtful either in law or in fact would be sustained. Finally the English courts and some American courts held that though the claim be obviously unfounded yet if it were honestly made the compromise was good. In Callisher $v$. Bischoffsheim ${ }^{32}$ it was said: "If he bona fide believes he has a fair chance of success, he has a reasonable ground for suing, and his forbearance to sue will constitute a good consideration." That sort of reasonableness is plainly just good faith. In Ockford $v$. Barelli3 a young woman married her uncle and claimed as his widow. The heirs compromised. It was held that the compromise was enforceable. If reasonableness means anything more than honesty, the case seems insupportable. On the other hand there are many dicta and a few decisions in this country which seem to require the reasonableness which the Restatement demands. Some of these appear to be but a different name for the "doubtful" claim variety of rule.34 Of course the lack of doubt as to the validity of a claim seems to be almost identical with unreasonableness. Does the Restatement adopt the "doubtful" test? Again it is clear that unreasonableness, whatever it may mean, would be some evidence of bad faith. It seems that therein lies its true significance. In favor of an unqualified "good faith" rule, the following suggestions may be made: (a) It is a legal detriment to surrender or forbear suit on a bona fide claim. One has both the legal and, it seems, the moral right to test an honest claim in the courts even though he be unreasonable. (b) One can know whether he acted in good faith but it may be difficult for a layman or even for a lawyer to know when a claim is reasonable. Yet by the Restatement no compromise is effected unless this reasonableness is present. A lawsuit is necessary to discover whether one's rights are on the compromise or on the original claim. (c) If the principle of Sereard v. Mitchelt ${ }^{35}$ be applied (that it is not the possibility of detriment, but the taking of a chance of detriment so far as the promisee knows, that is the ultimate minimum of consideration) then the surrender of an honest claim would seem to be good. But the Restatement, consistently, has quah-

32 (1870) 5 Q. B. $449,452$.

33 (1871) 20 W. R. 116, 25 L. T. R. 504.

34 Allen v. Prater (1859) 35 Ala. 169; Crawford v. Engram (1908) 157 Ala. 314,47 So. 712.

35 (1860) 1 Coldw. (Tenn.) 87. The section of the Restatement stating this matter is $\$ 84(f)$. 
fied Seward v. Mitchell by injecting reasonableness there also. On the whole the adoption of this undefined test of "reasonableness" seems undesirable in that it strikes down some bargains honestly entered into by fully competent parties for legitimate purposes.

In Section 76, Mllustration 8, a subsequent contract for extra compensation with no evidence of rescission or modification of the prior contract is stated and condemned as the "orthodox" theory would compel, the contractor doing only what he is already bound to do. Then this sentence is added:

"If unforeseen difficulties justifying $A$ in rescinding the contract exist, there is sufficient consideration for a promise of additional payment."

This statement is consistent with that in Comment $\mathrm{c}$ to Section 76:

"One who may at will avoid a legal relation is not under a duty within the meaning of the section."

For present purposes the accuracy of this is conceded. ${ }^{38}$ Here we are interested in the implication that unless the unforeseen difficulties would warrant rescission the consideration would be insufficient. This accords with the solution preferred in Professor Williston's treatise on contracts. $^{37}$ If we may take this implication as the position of the Restatement, dissent is in order. The chief basis in reason for the "orthodox" theory is that it prevents extortion by the party getting more or giving less than he was bound to give..$^{38}$ When unforeseen difficulties arise it is apparent that the contractor is the suffering party and that a promise to adjust the situation is equitable and should be enforced. There are well-reasoned cases decided by courts of high standing for this position. ${ }^{39}$ Why must they be disregarded in order

36 There is a discussion of it below at page 635 .

371 WIILISTON, CoNTRACTS (1920) \$130a.

38 See supra 615.

39 In the following cases unexpected difficulties developed wbich probably did not excuse the contractor. The decisions were not based on the presence of such an excuse. In none of them was there a new consideration or a change of obligation on both sides except as noted below. They would be condemned therefore by Professor Williston's reasoming in \$130a. (1 WILLISTON, Contracts (1920) \$130a.) In the following the new contract was substituted for tha old: Connelly v. Devoe (1871) 37 Conn. 570; Linz v. Schuck (1907) 106 Md. 220, 67 Atl. 286, 11 L. R. A. (N. s.) 789, 124 Am. St. Rep. 481, 14 Ann. Cas. 495 ; King v. Chicago, Milwaukee \& St. Paul Ry. Co. (1895) 61 Minn. 482, 63 N. W. 1105, semble; Osborne v. O'Reilly (1887) 42 N. J. Eq. 467, 12 Atl. 377 (perhaps based on misrepresentations making the first contract rescindable); Washington Insurance Co. v. Reinhardt (1912) 142 S. W. 596 (Tex. Civ. App.) (there was a new consideration present but the decision is not rested on it). In the following cases the new contract was to modify the old: United States v. Cook (1921) 257 U. S. 523, 42 Sup. Ct. 200 (an excellent discussion); Umited Steel Company v. Casey (C. C. A. 6th, 1920) 262 Fed. 889 (perhaps there were misrepresentations making the first contract rescindable); Blakeslee v. Board of Water Commissioners (1927) 106 Conn. 642, 
to maintain unimpaired the application of the "orthodox" theory? The reason ceasing, namely, the danger of extortion, the rule should cease.

One of the many excellent positions of the Restatement is that an antecedent obligation to a third party of a contractual or quasi-contractual nature does not prevent the performance of an act or the promise of such a performance from being a sufficient consideration. ${ }^{40}$ The majority of cases is concededly against this position but the argument for it is unanswerable. Granting that there is no detriment to the party already bound, the answer is that there is a benefit to the new party since he procures an act or the promise of an act which lie liad no prior right to demand.

But why should the principle, thus approved when the prior obligations are contractual or quasi-contractual, be limited to those cases? Suppose $A$ and $B$ own adjoining homes and that $B$ is in Europe and his home unoccupied. Suppose further that $C$ without license trespasses on $B$ 's grounds and picnics there to $A$ 's annoyance. $A$ obviously has no right to exclude $C$ from $B^{\prime} s$ grounds. If $A$ promises to pay $C$ ten dollars if $C$ forbears to trespass further on $B$ 's lot and $C$ does forbear, what objection is there to the contract? It is true that by the "orthodox" theory there is no detriment to $C$. But a benefit to the promisor, $A$, is sufficient. $A$ has procured a course of conduct on the part of $C$ to which lie, $A$, had no prior claim.

Professor Williston's discussion of this matter ${ }^{41}$ starts with cases involving official duties owed to the public. Such cases seem distinguishable. Often there is a direct obligation to the person injured by the breach of official duty ${ }^{42}$ and when this is so there is no benefit to the new promisor since he already has a riglt to the performance. Further, in every case of official duty it is arguable that it would be against sound policy to let officers recover extra compensation of any

139 Atl. 106, 55 A. L. R. 1319 (a strong discussion); Bishop v. Busse (1873) 69 III. 403 (less satisfactory reasoning); Smith v. Gray (1925) 316 IIl. 488, 1477 N. E. 459 (modifications on both sides but decision not rested on that); Owen v. Button (1911) 210 Mass. 219, 96 N. E. 333 (change of obligation on both sides) ; Goebel v. Linn. (1882) 47 Mich 489, 11 N. W. 284, 41 Am. Rep. 723 (a good discussion but close to the line on the question of extortion which the court held was not present) ; Meech v. City of Buffalo (1864) 29 N. Y. 198 (good statement); Gatlin v. Serpell (1904) 136 N. C. 202, 48 S. E. 631 (hazy reasoning and probably changes on both sides); Galveston v. Galveston City Ry. Co. (1877) 46 Tex. 435; Foley v. Storrie (1893) 4 Tex. Civ. App. 377, 23 S. W. 442 ; Carstens v. Burleigh (1898) 20 Wash. 283, 55 Pac. 221, senıble. Likewise if a collateral mistake by one party causing him to make a disadvantageous contract makes an adjustment equitable, the law does not forbid it. Cooke v. Murplyy (1873) 70 Ill. 96.

10 Contracts Restatement (Am. L. Inst. 1928) \$\$76a and 84(d).

11 WIIISTON, CoNTRACTS (1920) \$132.

42 See 46 C. J. 1042-1045. 
kind for doing their duty since they should be swift to perform that duty and should be free from temptation to delay in the hope of attractive offers for performing it. Common carrier cases are considered next by Professor Williston. Here also the promisor often has a prior individual right against the carrier and the new contract is therefore condemned by the "orthodox" view. The public policy argument also may be urged: corporations engaged in furnishing services to the public under franchises have a great power to injure individuals by discrimination. Very many of the remaining cases referred to by Professor Williston fall in one or the other of these same two categories, either there was an enforceable obligation in favor of the promisor or a sound public policy required that the contract be condemned as in the case of a promise to pay a witness more than established fees for appearing and testifying as he is bound to do. There is also the possibility that in any case the breach of legal duty may in fact be used as a means of extortion and thus render the contract voidable. The residuum of cases, if any, may well be ignored as over-zealous applications of the "orthodox" theory just as the Restating Committee ignored the majority of cases opposed to their view that a contractual duty owing to a third party does not prevent consideration.

The Restatement also makes insufficient as consideration the forbearance to commit a crime. ${ }^{43}$ The same arguments apply. The obligation not to steal a given chattel may be owing to the very person who makes the promise. Public policy may demand that no one be paid for refraining from murder or arson. Certainly the threat of crime may be duress, undue influence or extortion. But suppose grandma promises Charles twenty-five dollars if he will forbear to violate the speed laws for a year and Charles, mirabile dictu, does forbear. Charles hardly owes grandma any duty to drive within the law. Public policy, it seems, would rather favor such contracts. Extortion might be wholly lacking: indeed the pressure seems to be coming from grandma. The Restatement forbids such a contract. But the arguments in favor of Section 84 (d) apply with equal force here.

Section 76 (a), if the above suggestions appeal, should he simplified to read:

An act or forbearance [is not a sufficient consideration if] required

by a legal duty that is neither doubtful nor honestly considered doubtful provided the duty is owing to the promisor.

Separate sections would deal with the public policy and extortion cases. Such sections would naturally be placed with later material concerning illegality and voidability for duress and the like. This is

43 Contracts Restatement (Am. L. Inst. 1928) §76a. 
not a mere difference in the form of statement. It avoids the unyielding condemnation of all contracts to forbear torts, crimes or other violations of duty. It applies tests which rest on the reasons for refusing enforcement of many such contracts and makes it possible to uphold those where the possible objections are absent.

While we are considering Section 76 we must not neglect subsection (c). It denies the validity, to take the typical case as an illustration, of a contract in which the consideration is paying fifty dollars on January 1, 1930, at the $X$ bank in New York City and the promise is to pay one hundred dollars on that same day and at that same place. Few people will wish to exchange unequal sums of money on the same day and at the sane place. If done, the delivery of the excess money would plainly take effect as a gift. If not done, the pronise is broken at the end of the day set, the very day on which it was to become binding. The writer doubts the existence of any case involving such facts in all our voluminous law reports. Why a separate subsection to condemn such a rather foolish but innocuous contract? It is possible that the answer is found in Williston on Contracts, Section 115. There the same statement is made as is contained in this subsection (c) and for the statenient the well-known case of Schnell v. Nell ${ }^{44}$ is cited with two similar cases. But Schnell v. Nell was different. There one cent was to be paid on the day of the contract for a promise of six hundred dollars to be paid in three equal installments in one, two and three years. Professor Williston's own note says:

"Any difference in place or medium of payment or priority in time will make the smaller payment sufficient consideration."

So he believes that Schnell v. Nell, supra, was erroneously decided. The writer heartily agrees. Now can we get rid of Schnell v. Nell by citing it for the proposition contained in subsection (c), a proposition that can do no harm because the situation it deals with is substantially non-existent? These speculations are interesting. But the truth seems to be that subsection (c) should have been omitted entirely.

In Section 78 the Restatement declares that a pronise is an insufficient consideration unless the act promised would be a sufficient consideration for a unilateral contract. ${ }^{46}$ At first blush this seems rather self-evident. But on examination it proves to be a defensive position created to protect the "orthodox" theory from the inroads of

44 (1861) 17 Ind. 29, 79 Am. Dec. 453.

451 WIILISTON, Contracts (1920) \$115.

40 A limitation which makes a promise suffice as consideration when the promisor honestly and reasonably thought it would involve an act which would be a suficient consideration for a unilateral contract (cf. $\$ 84 f$ ) is omitted as beside the point to be discussed. 
logic. If a detriment to the promisee or a benefit to the promisor is the requirement, it cannot be logically denied that sometimes a promise is a detriment when performance of the act promised would not be. If $D$ owes five dollars to $P$ which is overdue, the payment of that five dollars is no detriment to $D$ as long as the "orthodox" view stands. But a new promise to pay that five dollars is a detriment to $D$ inasmuch as it waives the statute of limitations up to the time of the promise. Again, if we ignore benefit to the promisor, as the majority of cases do, then the performance of an act which one is bound to a third party to do is not a legal detriment by the "orthodox" view. But the promise to do the act made to the present new party is a detriment because by such a promise he becomes hable to this new and second person. ${ }^{47}$ So Section .78 in truth provides that a detriment to the promisee is not in certain cases a consideration. Put in that way it is not so self-evident. It is rather one of the phrases by which the "orthodox" theory strikes down legitimate bargains between competent persons despite the presence of a detriment to the promisee which is generally said to be a sufficient consideration. It must be admitted that, laying exceptional cases aside, the general course of decision is in accord with this heavyhanded position. But in nearly all the cases there has been no apparent apprchension of the opposite view. If the argnments for the suggestions lere made seem technical, the answer is that they lead to the enforcement of legitimate business transactions and that should induce us to give them every ounce of weight to which they are entitled.

By the terms of Section 80 a void promise is an insufficient consideration. Suppose an actress is promised a salary for taking part in a play in which leer only lines consist of a promise on her part to marry the hero. No one will doubt that her promise to the hero is not binding. No one will doubt that the actress may recover her compensation. One answer will be that here the promise is an act. Perhaps then the comment on this section or an illustration should have pointed to this distinction. Another answer will be that the actress did other

47 Nor can it for a moment be admitted that to so argue is circular and a hegging of the question. Since the fifteen hundreds our law has held simple bilateral contracts valid. This law must be applied when we are discussing the sufficiency of a promise as consideration. It must mean that a promise exchanged for another promise is valid unless there are further facts, such as coverture at common law or that the promise was made by a corporation and is ultra vires, which make it nugatory. An ordinary bilateral contract hetween competent partics is then effective. Now the fact that a promise is to do what one is bound to do does not destroy it as a promise. When an act is given for such a promise the promise is perfectly enforceable. 1 Wrisiston, Conrracts (1920) $\$ 131 \mathrm{~b}$. So a promise ta do what you are bound to a third party to do is valid and subjects you to a new obligation and is just as certainly a detriment as any promise in any bilateral contract. 
things than speak her lines. But cases may be supposed where such other acts are absent. But the writer believes that the section under discussion is open to a deeper criticism in that it substitutes a rigid rule for a flexible principle. The reason why non-binding promises are generally not a consideration is because the other party expected and impliedly asked for a valid effective promise. If in fact he expressly took a promise known to him to create no legal obligation, it is hard to see any reason why his own promise given in exchange should not bind him. The non-binding promise is surely as valuable as a peppercorn. Adequacy is immaterial. However few such last supposed contracts will be made. Little harm may be done.

But a cognate question arises when a promise is voidable by an act of the promisor. Is such a promise also a nullity and therefore no consideration? By Illustration 1 to Section 79, by Section 84 (e) and by the comment on Section 84 (e) it appears that the Restatement condemns a promise which the contract expressly makes voidable by the promisor though it admits that a promise made voidable by law is a sufficient consideration. One would naturally expect the solution of these problems to be exactly the opposite. When one willingly takes a voidable promise as consideration he gets just what he bargained for and should be held: when one expects to receive a normal promise fully binding and because of facts unknown to him the promise is voidable under the law, he certainly does not get the consideration he sought. If to an ordinary offer one sent back an acceptance qualified by making the acceptor's promise voidable, all would agree that the acceptance was ineffective and that mutual assent was lacking. The infancy, insanity, statute of frauds, and like cases where the return promise is voidable or unenforceable can only be explained as based on the policy of the law concerning persons under disability or on the true interpretation of the statute of frauds or on similar matters extraneous to the law of normal contracts. Such explanations seem sufficient.

To come then to a promise expressly made voidable by the contract, what objection can there be to that as consideration? It is the intended consideration. But it is urged that it has no value. ${ }^{48}$ It has all the value that $a$ voidable promise of a minor or of an insane person has. But casting such cases aside as exceptional, it remains true that a voidable promise is a detriment and has value. Prior to the making of the promise the promisor need do nothing: after the making he must either perform the promise or give such notice as will avoid it. Either alternative is a detriment and the inadequacy of the second alternative should not by the well-known principle render it an msufficient con-

481 WrLtiston, Contracts (1920) $\$ 105$. 
sideration. A promise to perform if the promisor wishes or if he gives notice that he will, is altogether different. There the promisor is as free to do nothing after the promise as he was before it was made. The distinction may be considered technical by some. But look at the consequences of not taking it. Many actual contracts are made voidable by one or by either party. They are business transactions entered into by competent persons. Must we blind ourselves to a fine distinction and thus strike them down? If one must be blind, the writer would prefer to let the blindness lead him to think that illusory promises involve a detriment and so may serve as consideration. In dealing with this highly techmical requirement of consideration we must not balk at techmical arguments that will prevent it from working injustice. A distinction is made in Illustration 1 to Section 79 where the promise can be avoided only by thirty days notice. Of course that ought to make the promise sufficient especially if, as in the illustration, there would be performance due within the thirty days. One cannot then avoid some performance of the promise and one is bound for an appreciable time. But when did adequacy of consideration become necessary in this class of cases? Where, also, is the line to be drawn? Will a notice of three days or three hours do? It is believed that the logical and simple place to draw the line is between promises that compel nothing from the promisor and promises that do compel some action however inadequate. That would make all promises which by their terms are binding until affirmatively avoided, valid as considerations. A canvass of the cases indicates that they sustain this view in the ratio of about two to one.49

49 Where some length of notice is required, that is noted. That a promise voidable by the terms of the contract is a sufficient consideration: Towers $v$. Barrett (1786) 1 T. R. 133, 99 Eng. Reprint 1014; Storm v. U. S. (1876) 94 U. S. 76, semble; Guffey v. Smith (1914) 237 U. S. 101, 35 Sup. Ct. 526; Ellis v. Dodge Bros. (C. C. A. 5th, 1917) 246 Fed. 764 (15 days notice); Chevrolet Co. v. McCullough Motor Co. (C. C. A. 9th, 1925) 6 F. (2d) 212 (five days notice; but gave plaintiff only nominal damages on ground that such a terminable contract did not give plaintiff a right to more than five days performance); McIntyre Lumber \& Export Co. v. Jackson Lumber Co. (1910) 165 Ala. 268, 51 So. 767, 138 Am. St. Rep. 66; White Co. v. American Motor Car Co. (1912) 11 Ga. App. 285, 75 S. E. 345; Watford Co. v. Shipman (1908) 233 IIP. 9, 84 N. E. 53, 122 Am. St. Rep. 144, semble; Poe v. Ulrey (1908) 233 Ill. 56, 84 N. E. 46; Black V. Consolidated Independent School District (1928) 206 Ia. 1386, $222 \mathrm{~N}$. W. 350, semble; Pittsburg Co. v. Bailey (1907) 76 Kan. 42, 90 Pac. 803, 12 L. R. A. (N. S.) 745; Farmer's Handy Wagon Co. v. Newcomb (1916) 192 Mich. 634 159 N. W. 152; Garlock v. Motz Tire \& Rubber Co. (1916) 192 Mich. 665, 159 N. W. 344; Clinton Co. v. French (1921) 214 Mich. 447, 183 N. W. 68; McCall Co. v. Wright (1909) 133 App. Div. 62, 117 N. Y. Supp. 775 (30 days notice); MeCall Co. v. Wright (1910) 198 N. Y. 143, 91 N. E. 516, 31 L. R. A. (N. s.) 249 (last case on appeal and affirmed with extended discussion); Realty Advertising \& Supply Co. v. Englebert Tire Co. (1915) 89 Misc. Rep. 371, 151 N. Y. 


\section{CONTRACTS WITHOUT CONSIDERATION}

In Sections 85 to 94 the Restating Committee insists that certain simple contracts are enforced despite a total lack of consideration. Why should one who thinks the doctrine of consideration highly technical and ill-adapted to its purposes, attempt to combat the Restatement's concession that sometimes it is not applied? The answer is that the Restatement in conceding these exceptional cases, by implication extends the doctrine of consideration to the entire class of transactions, of which these are illustrations. The writer does not believe that the doctrine of consideration should be thus extended. There are three kinds of situations to which the doctrine of consideration might be applied: (a) The creation of new contract obligations. (b) The discharge of existing contract obligations. (c) The waiver of defenses to existing obligations. There can be no doubt that at present it is generally applied in the first two classes of cases: a consideration is necesary to bind one to a promise to convey land and a consideration is equally required to make effectual a surrender of the right to the land assuming that the promise to convey it had become binding. But in the third class of cases it is by no means settled that a consideration is required. The Restatement by clear implication requires it, except in the limited number of situations where it was compelled to admit that no such requirement existed. That such is the result of the Re-

Supp. 885 (five days notice) ; Fawcett v. Fawcett (1926)' 191 N. C. 679, 132 S. E. 796; Central Ohio Natural Gas \& Fuel Co. v. Eckert (1904) 70 Ohio St. 127, 71 N. E. 281; Philadelphia Club v. Lajoie (1902) 202 Pa. 210, 51 Atl. 973, 58 L. R. A. 227, 90 Am. St. Rep. 627; Taber v. Dallas County (1908) 101 Tex. 241, 106 S. W. 332 (non-payment of interest for sixty days); Lovette v. Eastern Oil Co. (1911) $68 \mathrm{~W}$. Va. 667,70 S. E. 707, Ann. Cas. 1912B 360, semble; Woodward v. Smith (1901) 109 Wis. 607,85 N. W. 424.

That a promise voidable by the terms of the contract is not a sufficient consideration: Reese v. Zinn (C. C. D. W. Va. 1900) 103 Fed. 97; Velie Motor Car Co. v. Kopmeier Motor Car Co. (C. C. A. 7th, 1912) 194 Fed. 324 (perhaps the leading case for this view); Oakland Motor Car Co. v. Indiana Automobile Co. (C. C. A. 7th, 1912) 201 Fed. 499; Ellis v. Dodge Bros. (N. D. Ga. 1916) 237 Fed. 860 (reversed by the Circuit Court of Appeals in a decision cited in the opposing list); Skeen v. Ellis (1912) 105 Ark. 513, 152 S. W. 153, semble; Shortell v. Corporation (1929) 98 Cal. App. 650, 277 Pac. 519; Nicolls v. Wetmore (1916) 174 Ia. 132, 156 N. W. 319, semble; Hunt v. Livermore (1827) 5 Pick. (Mass.) 395, semble; Great Northern Ry. Co. v. Sheyenne Telephone Co. (1914) 27 N. D. 256, 145 N. W. 1062, semble; Brown v. Wilson (1916) 58 Okl. 392, 160 Pac. 94, L. R. A. 1917B 1184, semble; American Agricultural Chemical Co. v. Kennedy \& Crawford (1904) 103 Va. 171, 48 S. E. 868; Lydick v. Baltimore \& Ohio R. Co. (1880) 17 W. Va. 427; Eclipse Oil Co. v. South Penn. Co. (1899) 47 W. Va. 84, 34 S. E. 923 ; Trees v. Eclipse Oil Co. (1899) 47 W. Va. 107, 34 S. E. 933 ; Pyle v. Henderson (1909) 65 W. Va. 39, 63 S. E. 762, semble; White v. McCullagh (1914) 74 W. Va. 160,81 S. E. 720 , semble. 
statement is evidenced further by the fact that that position is expressly taken by Professor Williston in his treatise on Contracts. He says:

"A bare agreement to surrender defenses other than those within the special classes under consideration is not generally recognized as binding." $" 50$

The authority cited for this statement is certainly very unsatisfactory. ${ }^{51}$ One case concerns an acknowledgment removing the bar of the statute of limitations and so is within, not outside "the special classes." The remaining two cases did not concern the surrender of a defense to a contract at all. But the statement indicates Professor Williston's view which apparently has been adopted as the basis of this part of the Restatement. But why should the authors of the Restatenient encourage this extension of the requirement of consideration to new fields? Has it not been difficult enough to apply it consistently and without injustice to the creation and to the discharge of contract rights where it is settled that it must be applied?

We come then to the question: Are the cases permitting the ratification of a contract made during minority or while insane, permilting the affirmance of contracts voidable for fraud, duress and the like, permitting the surrender of such defenses as the statute of limitations, discharge in bankruptcy or breach of condition, best explained as anonalous new contracts created without consideration or mutual assent as the Restatement maintains, or are they best explained as waivers of defenses to existent but obviously defective contract rights? The subject is a large one and only a very summary discussion of the argunients is possible here.

501 WIIIISTON, Contracts (1920) \$203.

51 As stated in the text one case (Green v. Coos Bay Wagon Road Co. (C. C. D. Ore. 1885) 23 Fed. 67) simply stated that an acknowledgment of a debt interrupts the running of the statute of limitations and starts it running ancw though it preferred to call this a new promise with the old debt as consideration rather than a waiver. A second case (Danforth v. Pratt (1856) 42 Me. 50) correctly held that a lien on a horse could not be surrendered merely by a gratuitous promise to surrender. But a lien is not a contract right with a defense to it. The remaining case (Monkman v. Shepherdson (1840) 11 A. \& E. 411) correctly held that when a contract right is destroyed by act of the parties it cannot be recreated by a gratuitous promise or waiver. Usually in such cases the destruction of the right results froun a subsequent contract as in Grant v. Porter (1884) $63 \mathrm{~N}$. H. 229. But it may equally result from provisions of the original contract itself as in Monkman v. Shepherdson. It was not a case of payment being conditional on the plaintiff remaining sober but an agreenent that should the plaintiff get drunk lie would thereby extinguish his right to all wages then due. If it should be argued that it was a promise to pay subject to a condition subsequent then the case still does not support Professor Williston's statement because it then does not concern a defense "other than those within the special classes." 
(a) In the note to Topic D, on page 244 of the Official Draft, one reads:

"On reflection, however, it is evident that when one who has never been bound by a contract, or who has ceased to be so, makes a promise and is then held bound, when he has received nothing for the promise, and when ... no communication has passed to him from the promisee, a promise is enforced without the ordinary requisites of an expression of assent and consideration."20

Perhaps the words italicized give us a clue to the thought underlying the Restatement's position. It is that in these special cases one either never was bound or is no longer bound. Illustrations of the first alternative supposedly would be either obligations subject to a condition precedent which was broken or obligations voidable $a b$ initio either by law or contract. Illustrations of the second alternative would be obligations the enforcement of which is barred by the statute of limitations or a discharge in bankruptcy. If in these cases it is true either that there never was an obligation or that it has ceased to exist, the Restatement's position is defensible. The ratification, affirmance, new promise or whatever form it may take, cannot then be a waiver of a defense as a defense presupposes an existing right and a corresponding obligation. But this underlying conception that there is no obligation in these cases prior to the new transaction seems entirely unfounded in law.

With regard to all voidable contracts (infancy, insanity, fraud duress, and the others) one need only refer to Professor Williston's own discussion. He says:

"Where the defense is of this nature it is not the new promise or ratification so called which gives rise to the right of action. Rather it is true that the defence or privilege given by the law never extended beyond permitting the defendant when apprised of the facts on which his rights depend to withdraw from the transaction."53

If the new promise, in these cases, does not give rise to the right of action, it must be based on the old obligation which accordingly cannot be considered as either always or now non-existent. Again, the fact that a promise voidable by law is a sufficient consideration for a counterpromise ${ }^{54}$ indicates rather conclusively that a voidable pronnise is not void.

With regard to contracts whose enforcement is barred by a statute of limitations or a discharge in bankruptcy one must examine the authorities which bear upon the question. It may be conceded at once

52 Italics added.

531 WIILISTON, CoNTracts (1920) \$204.

54 Contracts Restatearent (Am. L. Inst. 1928) §84e. 
that no action will lie to directly enforce obligations thus barred. But the existence or non-existence of such obligations may become collaterally important in many other ways. Professor Williston has answered the question, so far as rights barred by the statute of limitations goes. He says:

". . . most American courts have held that the Statute of Limitations merely bars the remedy of the creditor but does not totally discharge the right."55

His citations are numerous and in point. In Bickerdike v. State ${ }^{50}$ it appeared that a claim against the State of California was barred by the local statute of limitations and that the legislature passed an act waiving the bar for a class of cases including the instant case. This act was attacked as unconstitutional because the California Constitution forbids the legislature to make gifts of public money. But the act was upheld on the ground that the statute did not make a gift but merely waived a defense to an otherwise valid and existing right of action.

While the authorities concerning the continued existence of a debt discharged in bankruptcy are much less numerous, it still seems clear that the debt is only rendered unenforceable and is not extinguished. ${ }^{57}$

There remain the cases as to conditional contracts when a condition is unperformed. It is obvious that there is no inherent reason requiring one to decide that a breach of condition discharges the promise which it qualifies. Undoubtedly unless and until the breach of condition is "waived" or otherwise cured it is a perfect defense to an action on the contract. The fact that it can be "waived" favors the view that such a breach is merely a defense. When a right is really discharged it cannot be recreated without consideration..$^{58}$ At least one class of cases indicates that the riglt persists though the direct remedy is gone. These are cases deciding that despite a substantial breach of a bilateral contract by one party, a mutual rescission of the contract is valid. ${ }^{59}$ If the party in default had lost all his rights by the

553 WIIIISTON, CONTRACTS (1920) \$2002.

56 (1904) 144 Cal. 681, 78 Pac. 270.

57 Webster v. Le Compte (1891) 74 Md. 249, 22 Atl. 232; Citizen's Loan Association v. Boston \& Maine R. (1907) 196 Mass. 528, 82 N. E. 696, 14 L. R. A. (N. s.) 1025, 124 Am. St. Rep. 584; Craig v. Seitz (1886) 63 Mich. 727, 30 N. W. 347, semble; Stanek v. White (1927) 172 Minn. 390, 215 N. W. 784, semble; Badger v. Gilmore (1856) 33 N. H. 361. See also 7 C. J. 395-6, 410; 5 PAGE, Contracts (2d ed. 1920) \$3166. And a discharge in bankruptcy of one joint debtor does not discharge the others. 1 WIIIISTON, Contracts (1920) $\$ 329$.

581 WIIIISTON, Contracts (1920) \$159.

593 WIIIISTON, Contracts (1920) \$1826. See in addition: Rogers Co. v. Southern California Co. (1911) 159 Cal. 735, 115 Pac. 934, 35 L. R. A. (N. s.) 543; Cutter v. Cochrane (1874) 116 Mass. 408. Of course all cases bolding that the substitution of a new contract for a broken bilateral contract though the 
breach, there would be no consideration for the surrender of the other party's rights.

Thus it seems that in all these "special classes" the truth is that the promisor was bound originally and still is bound though in part of the cases the obligation was voidable $a b$ initio and in the others it lias become unenforceable. The Restatement of course recognizes the existence of voidable and unenforceable obligations. ${ }^{80}$

It follows that the Restatement's position, so far as based on the absence of obligation prior to the new promise or waiver, is unjustified by the facts. Obligations do exist though they are subject to defenses. If defenses may be waived then the enforceability of these obligations after the ratification or acknowledgment may well be explained on the doctrine of waiver. The Restatement and Professor Williston in his treatise are forced to admit that gratuitous surrender of defenses is allowed in these special cases. As to other cases they have furnished us with no authority against the effectiveness of waiver.

(b) The authors of the Restatement liave to concede that to treat these waivers of defenses as contracts requires an admission that they lack the requirement of mutual assent as well as that of consideration. ${ }^{61}$ Rather curious contracts! As waivers of defenses they do not involve any such legal oddities. Waivers are acts by one person requiring neither mutual assent nor consideration.

(c) The Restatement also admits" that these anomalous "contracts" are invalid unless made with a knowledge of the facts involved in the previous transaction. But this again argues that they are not contracts, for a knowledge of all material facts is not essential to the validity of a contract. When there is knowledge of the terms of the contract and agreement upon them, it is only in exceptional cases, falling either under the so-called doctrine of "impossibility" or under a very himited doctrine of equity concerning rescission for mistake by one party, that mere lack of knowledge of facts or even affirmative mistake as to facts makes any difference. But it is generally and reasonably held that a waiver must be made with a knowledge of the pertinent facts which create the defense.

(d) Again it is clear that a promise which exceeded in any way the old defective obligation would be invalid. If the barred debt were for $\$ 100.00$, a promise of $\$ 200.00$ could not be enforced. In Section 86 ,

change in the new contract favors one party only, also rest as to consideration on the rescission of the old contract and are further authorities that rescission of a broken contract is possible without a new consideration.

60 Expressly in $\$ \$ 13$ and 14.

01 Ibid. \$85.

62 Ibid. $\$ 93$. 
Illustration 11, this principle is recognized in an analogous case. But in no case is a promisor in a true contract limited as to what he may promise. As contracts these cases stand alone. The limitation is an obvious necessity if waiver of defenses is the true explanation.

(e) By Section 86 (2) (a) and Section 86 (2) (b) it appears also that these curious contracts need contain no promise. This is camouflaged by declaring that an acknowledgment of a debt or a part payment of it is necessarily a new promise to pay the balance due - an obvious fiction. A contract without promise, mutual assent or consideration seems unthinkable. If waiver be taken as the true explanation, an acknowledgment or part payment may well be considered as conduct inconsistent with an intention to rely on the defense and so as a waiver of it.

(f) By Section 88 (2) it is provided that in the case of certain of these "contracts" the "promisor" can back out of his promise after having once made it. This also is astounding. Generally when one becomes bound by a contract he cannot withdraw unless the right is reserved in the contract or is given by law because of incapacity of the promisor or wrong doing by the promise. Consider these cases as illustrations of waiver and the result is reasonable. Since the waiver is gratuitous it is only fair to let it be withdrawn any time before the other party has changed his position in reliance on it. Likewise the cases that go furthest in holding gratuitous licenses irrevocable do so only after the licensee has changed his position in reliance on the license.

(g) When enforceability is established or reëstablished, are your rights measured by the old obligation or the new promise? We have already noted that the old obligation is the maximum that the new promise can validly assume. But aside from that dominance of the old obligation, it is probable that rights are measured by the old obligation in most cases. One must distinguish at once the settled rule that if the "waiver" is conditional or partial it is effective only as made. This does not indicate that the transaction is a new undertaking but only that one who has the power to waive a defense fully also has the power to waive it partially or conditionally. When, however, the waiver is unlimited, is the obligee's right measured by the old obligation or by a supposed new one. The old may be under seal, subject to a statute of limitations of ten years, negotiable. The new promise, if the waiver takes the form of a promise, may be not under

${ }^{63}$ See the Restatement's note to $\$ 92 ; 1$ WinLIston, Contracts (1920) $\$ 175$; 16 AMr. \& Eng. Ency. of Law 792; 13 EncX. PL. \& Pr. 247; 25 Cyc. 1329, 1364, $1365 ; 5$ PaGe, Contracts (2d ed. 1920) $\$ \$ 3168,3491$. 
seal, subject to a statute of limitations of but four years, non-negotiable. On these problems the cases are in great conflict. ${ }^{63}$ It is difficult to know which view is best supported. On the waiver view the old obligation should govern. On the Restatement's view the new "promise" should govern. One is surprised then to find this statement in Comment $b$ to Section 92 :

"... and after the new promise is made, as well as before, the right of the promisee will be negotiable or assignable, depending on the character of the original duty and of the renewal promise."

But this does not tell us which view is adopted. The only further hight given is found in Mlustrations 2 and 3 to the same section. These apparently declare that negotiable obligations, to which a defense has been waived by a non-negotiable promise, are still negotiable. This result appeals but is rather inconsistent with the general position of the Restatement.

(h) By Section 92 the "new promise" must be made to the person "to whom the money is then due." This would naturally enough be correct by either theory. A waiver should be communicated to the person in whose favor it is made. But the interesting thing is that the new doctrine of the Restatement, that in these cases the prior obligation either never existed or has ended, is so new and so strange that here the Restatement itself forgot about it and provided that the new promise must be made to the person "to whom the money is then due.".

(i) Lastly a word may be said about the origin of this power of reviving barred claims. Professor Williston has said:

"The truth should be recognized that the cases in question in the main are survivals of the early rule, based on a fiction originally and still fictitious, that an antecedent debt is consideration for a subsequent promise to pay it." 64

This of course recalls Slade's Case. ${ }^{65}$ But the two doctrines seem to have little in common. In Slade's Case there was a cause of action perfectly suable in debt. To avoid the disadvantages of debt as a form of action, chiefly wager of law by the defendant, it was held that the creditor could sue in assumpsit. A fictitious new promise, with the old debt as consideration, was set up to bring the case nominally within the bounds of assumpsit. But in the cases now under discussion the difficulty has no relation to forms of action. The trouble is that the plaintiff has no suable claim. The "new promise" or "waiver" is not fictitious but real. The writer's reading of the early cases disclosed little or no trace of any connection between the two doctrines. On the

641 WIITISTON, CONTRACTS (1920) §201.

65 (1602) 4 Coke 92b, 76 Eng. Reprint 1074. 
other hand in Heyling v. Hastings, ${ }^{66}$ decided in 1699 , the court holds that a suit may be maintained because the defendant had "waived" the benefit of the statute.

In any event it is certain that the chief influence in shaping the law was a notion that the "new promise" must not be a variance from the original obligation. ${ }^{67}$ This accounts for, though it does not justify, the decisions that you cannot waive the statute of himitations as to a tort. If a tort were alleged in a declaration and to a plea of the statute of limitations the plaintiff alleged a promise to pay within six years, the courts condemned the replication as varying from the declaration and accordingly a departure. ${ }^{68}$ That the statute cannot be waived as to torts is then no argument that waiver of defenses in general is not allowed. It was rather an accidental and erroneous result of the misapplication of the doctrines of variance and departure.

There is more that might be said against these considerationless contracts which the Restatement has proposed. But there must be an end. The writer is not one who cares much about what theory one holds unless his theory leads to undesirable results. As was stated at the outset of this discussion of "waivers," the objection to the Restatement's position is that it would extend the doctrine of consideration to the field of waiving defenses and thereby would prevent the reasonable growth of the doctrine of waiver to which growth the writer sees no practical objections.

\section{SOME OTHER SUGGESTIONS}

Section 88 (1) provides that a new promise to perform despite a breach of condition by the other party, is effective unless either the performance of the condition was a substantial part of the exchange or the uncertainty of the happening of the condition was a substantial element in inducing the formation of the contract.

The first limitation on the general rule of the subsection seems to mean that a substantial breach in rendering the quid pro quo for the defendant's promise bars the plaintiff despite a plain waiver of that defense by the defendant. The writer insists that in such a case the defendant may waive the defense and thus make himself liable to a

66 (1699) 1 Ld. Ray. 389, 421, 91 Eng. Reprint 1157, 1179.

67 Dean v. Crane (1705) 1 Salk. 27, 91 Eng. Reprint 27; Williams v. Gun (1711) Fortes. 177, 92 Eng. Reprint 808; Tanner v. Smart (1827) 6 B. \& C. 603, 108 Eng. Reprint 573.

68 Hurst v. Parker (1817) 1 B. \& Ald. 92, 106 Eng. Reprint 34; Goodwyn v. Goodwyn (1854) $16 \mathrm{Ga}$. 114, semble; Nelson v. Petterson (1907) 229 Ill. 240, S2 N. E. 229,13 L. R. A. (N. s.) 912, 11 Ann. Cas. 178; Oothout v. Thompson (1822) 20 Johns. (N. Y.) 277; Avant v. Sweet (1803) 1 Brev. (S. C.) 228. 
suit on the contract by the party in default, ${ }^{69}$ though he will of course have a cross claim for damages caused by the breach, since a cause of action cannot be discharged without a consideration. There is in the Restatement no comment explaining this revolutionary position and there is no illustration that touches it. Is the hostility of the Restatement to the doctrine of "waiver" the cause of this attempt to limit it so strictly?

The second limitation is clarified by Mllustration 4. A fire insurance company cannot, it says, waive the condition to payment which requires a loss by fire. Undoubtedly that is so. But it seems a wrong classification to call the loss by fire the happening of a "condition." The truth is that the company's promise is to indemnify the insured against fire. It is a limited and special promise in addition to being subject to many express conditions. The company cannot increase the scope of its promise by a waiver, though it may surrender defenses arising from a breach of a condition to the promise. A promise to deliver potatoes grown on Whapload could not by waiver be increased into a promise to deliver potatoes generally. But if $A$ pronnises to buy and pay five thousand dollars for Greenacre if left that much by his grandmother's will, it would seem that he might waive the condition concerning the will even thougln the uncertainty of the happening was "a substantial element in inducing the formation of the contract."

Section $88(2)$ is very illiberal in so narrowly limiting the restoration of conditions after a waiver. The waiver should be considered revocable and the condition therefore restorable until there lias been such action on the waiver by an adverse party as would make it inequitable to allow a revocation or until the situation has so changed as to make performance of the condition impossible or substantially more burdensome. It is believed that the cases warrant such a position. To say, as does the Restatement, that the recall of the waiver must be made before the expiration of the tine originally set for the performance of the condition, seems unjustified.

Section 76, Comment c, provides that a prior duty will not affect the sufficiency of a consideration if the duty is voidable or if it has become unenforceable. These two propositions are assuredly correct. But there is a broader principle of which perhaps the two situations stated are illustrations. Whenever the avoidance of the duty is easily

60 Princess Amusement Co. v. Wells (C. C. A. 6th, 1921) 271 Fed. 226; Davis v. Robert (1889) 89 Ala. 402, 8 So. 114; Hermosa Co. v. Law Credit Co. (1917) 175 Cal. 493, 166 Pac. 22; Hills v. Edmund Peycke Co. (1910) 14 Cal. App. 32, 110 Pac. 1088; Milton Co. v. Butterfield (1927) 87 Cal. App. 772, 262 Pac. 419; Bell v. Smith (1868) 99 Mass. 617; Cahill v. Patterson (1858) 30 Vt. 592; Barry v. Danielson (1914) 78 Wash. 453, 139 Pac. 223, semble. 
possible and was or should have been contemplated then its existence does not affect consideration. Forbearance to smoke for thirty days is a consideration. If it appear that during the thirty days the one forbearing owned no tobacco, then it could be argued that he was under a duty not to smoke since smoking would involve the wrongful use of another's tobacco. The answer is that he may buy tobacco. True, but one under any contractual duty may ordinarily buy a release from such duty. The difference is that in the tobacco case the avoidance of the present duty not to smoke is easily possible and no doubt was contemplated, while the possible avoidance of the contractual duty ordinarily is difficult and not contemplated. This broader principle deserved a place in the text itself.

The phrase in this same comment which makes the prior duty immaterial if one may "refrain from any performance without legal consequences" is not so clearly right. A wife might neglect her husband to some extent, one may disturb or annoy another somewhat, one may be drunken and disorderly, all without any legal consequences. But refraining froin such conduct is not a consideration. ${ }^{70}$ There are duties which are recognized only in such collateral ways. But since escape from them is neither easy nor expected, they do make insufficient as consideration either their performance or a promise of such performance.

There is hittle doubt that the Restatement declares a nominal consideration, one agreed upon merely for the purpose of making the contract valid, sufficient. ${ }^{71}$ This is as it should be. Possibly an express statement on the matter would have been desirable.

Charitable subscriptions are no doubt vahidated by Section 90 when some substantial and expected action is taken in reliance on the subscription.

The important principle expressed in Section 76, Illustration 6, that variations froun one's duty will not make the consideration sufficient when they are just accidental differences not bargained for, should, it seems, have found a place in the text. The failure to recognize this principle has confused the reasoning in many cases. $A$ owes $B$ fifty dollars. If he pays $B$ thirty dollars in bank-notes or while wearing a green hat, would that make the part payment a sufficient consideration? Too often such questions have been answered by say-

70 White v. Bluett (1853) 23 L. J. Exch. N. S. 36; 1 WrLliston, Contracts (1920) \$133; Goodhart, Blackmail and Consideration in Contracts (1928) 44 L. Q. Rev. 436-450. But see Dunton v. Dunton (1892) 18 Vict. L. R. 114; Sharon v. Sharon (1885) 68 Cal. 29, 8 Pac. 614.

71 See Contracts Restatement (Am. L. Inst. 1928) $\$ \$ 75,76,76 \mathrm{a}, 81,84 \mathrm{c}$; Tllustration 1 to $\$ 82$, Mlustration 1 to $\$ 84$ and the notes to $\$ 84 a$. 
ing that there is no detriment, that payment in bank-notes when you might have paid in gold is no variation and cannot be a consideration. A sounder view is that such variations are detriments and may malse the partial payment sufficient, but that usually they do not accomplish this result because they are mere accidental differences not intended as an ingredient of the bargain.

Section 82 seems out of place. It would be much more easily understood in the general statement of the parol evidence rule. The writer, also, does not believe that this section expresses the law about recitals of consideration quite accurately. But a discussion of the matter would be rather extended and not very germane to the rest of this article.

In conclusion one must compliment the authors of the Restatement on the remarkable conciseness of the sections on consideration. The topic has great ramifications, yet nearly every question is answered in twenty rather short sections. It is a masterpiece of condensation. And, from the standpoint of one who thinks well of the law on the subject and wishes to see it perpetuated and strengthened, it is an accurate and able piece of work. Even one who is perhaps ultraliberal, can see that it will do fine service in helping to disentangle some of the snarls.

Clarke B. Whittier.

StANFORD UNIVERSTTY. 